\title{
BODY SECRETIONS GODDESS IN ANCIENT RELIGIOUS TEXTS
}

\author{
By
}

\author{
Rania 'Abdel 'Aziz Mahmoud
}

Lecturer at Faculty of Archeology, Fayoum University

\begin{abstract}
Water is considered the origin of everything, as, in the concept of the Ancient Egyptian, the universe came from the Eternal Ocean "Nun" which was in itself a god in the Ancient Egyptian Ideology. Water helps in performing many vital operations for human beings, as it helps in swallowing, digestion, distributing nutritious elements, and the process of excretion. Water helps in the balance of the human body, and it is the main component in the body of blood, Lymphatic fluid, Seminal fluid, Cerebrospinal fluid, as well as being part of the Body Secretions such as milk, tears, urine, sweat, ..., etc. Body Secretions carried significant symbolism and great reference in Ancient Egyptian religious texts, as it represented a means of protection against evils and dangers and against the punishment of the gods. The Secretions also caused rejuvenation of the heart and prevented exhausting it. Secretions were released from the body to remove illnesses and diseases and helped in the holiness and embodiment in the form of the gods, as well as mobilizing the gods for the sake of the deceased: «Isis», «Shu», «Horus», «Hw, «DwA-wr» the eight gods of «hhw». Secretions that came out of the spirits fell to fill the lakes and rivers.

Secretions were related to myths, such as creation myths and mythological locations, such as «Rostau» and the Island of Fire. Secretions also played an important role as they were connected to the gods and punishment of the hereafter, as well as the hope of the deceased not to have detestable Secretions that may ruin his body and lead to his annihilation or destruction.

In addition, the body expelled bad Secretions to get rid of rotten odors and be blessed with perfumes and good odors after that.
\end{abstract}

KEYWORDS: Secretions, Water, Sweat, Blood, Creation, Myth, Offerings, Island of Fire, Creation, Osiris. 


\section{INTRODUCTION}

Water is the origin of all living creatures as Allah the glorified and exalted be $\mathrm{He}$ said. This fact is not only common between celestial religions, but also the Egyptian Ideology recognized it. It is considered one of the creation theories in that water was also the origin of everything, as the universe originally emerged from the eternal ocean Nun that was in itself a god of the Ancient Egyptian ideology ${ }^{1}$.

\section{WATER AND MAN}

It is not arguable that human beings or living creatures, in general, cannot stay alive without water. Truly, the importance of water for human beings is clear and needs no evidence. In the beginning, the embryo is surrounded by a water sac in his mother's womb, and it is necessary to maintain the level of fluids in the mother's body so that it does not suffer any dryness which would negatively affect the embryo.

In human beings, water helps in making important processes necessary for human vital activity, as it helps in swallowing, digestion, distribution of nutritious elements on the body, as well as the process of Excretion.

If there is a shortage in water level in the body, this might lead to serious results that have bad effects on the health of the human. Additionally, many of the vital body elements are in liquid form and water represents the main component in it, such as: blood, the Lymphatic fluid, the Cerebrospinal fluid, the Seminal fluid, eye and Joint fluids. Also, Body Secretions take liquid forms, such as Urine, Sweat, Tears, Milk,..., etc. of the body secretions. ${ }^{2}$

The researcher handled a separate study about the Body Secretions for the Ancient Egyptian and their references in Ancient Egyptian texts ${ }^{3}$, which were not mentioned in a separate study, so the researcher reviewed the references related to water and its role in the Ancient Egyptian religious ideology. Some of the most famous references are:

1. 'ABBASY, A.S., Pediatrics, Faculty of Medicine, Dar El Maaref, Cairo, 1972.

2. ARNOLD, D, «Wasserspeier», LÄ vol. 6, Col.1155.

3. AtTiA, M., Notes on the under Land water in Egypt, Cairo, 1992.

4. BARTA, W., «Die Altagyptischeopferliste», MÄS 3, 1963.

5. In addition to that, there are related to the Ancient Egyptian texts. The researcher will start with the role of Body Secretions in the Pyramid Texts. BRUnNER-TraUt, E., «Schöpfung», L ̈̈ vol. 5, Cols. 677- 690 .

The study has used some words that refer to secretions. These words were handled in previous studies in addition to other fluids that have the same meanings and functions of body Secretions.

\footnotetext{
1 BRUNNER 1984: 677-690.

2 cABBASY 1972: 70-72.

3 For more information about water, its significant roles, and its relation to Body Secretions as a main constituent, See: BORCHARDT 1897: 128-130 f; KLEBS 1915: 90-92; BLACKMAN 1988: 5, 5(1-2); COLLINS 1991:4.
} 


\begin{tabular}{|c|c|c|c|}
\hline Word & Transliteration & Meaning & References \\
\hline 臯舟 & $m t w t$ & $\begin{array}{l}\text { Seminal fluid - } \\
\text { Secretions }\end{array}$ & $\begin{array}{l}\text { SETHE 1908: Spruch } 466 \mathrm{a}, 532 \mathrm{~b} \\
\text { ERMAN \& GRAPOW: } W b \text { vol.2 (eds.) } \\
169[5]\end{array}$ \\
\hline & hsmn & Blood Secretions - & $\begin{array}{l}\text { ERMAN \& GRAPOW: } W b \text { vol.3 (eds.) } \\
163 \text { (8-10). }\end{array}$ \\
\hline 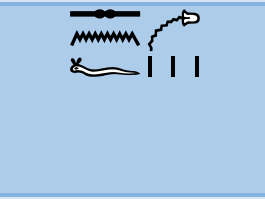 & snft & Blood Secretions- & $\begin{array}{l}\text { ERMAN \& GRAPOW: Wb vol.4 (eds.), } \\
\text { 459(5) } \\
\text { PEHAL \& PEININGER 2018: 114-136. } \\
\text { JANSEN } 2007: 81-107 .\end{array}$ \\
\hline$\Leftrightarrow \rightarrow \infty$ & $w s s ̌ t$ & Urine- Secretions & $\begin{array}{l}\text { ERMAN \& GRAPOW: } W b \text { vol.1 (eds.), } \\
\text { 358(1-3) } \\
\text { KADISH1979: } 205 .\end{array}$ \\
\hline 8 & $h s$ & Feces- Secretions & $\begin{array}{l}\text { ERMAN \& GRAPOW: } W b \text { vol.3 (eds.), } \\
\text { 164(4-9). } \\
\text { KADISH 1979: } 204 .\end{array}$ \\
\hline$\stackrel{\theta}{\circ U_{1}}$ & $h t p-k 3$ & Feces- Secretions & $\begin{array}{l}\text { KADISH 1979: 204. ERMAN \& } \\
\text { GRAPOW: } W b \text { vol.3 (eds.), 195(1). }\end{array}$ \\
\hline
\end{tabular}

\section{Pyramid Texts:}

Body Secretions carried important symbolism and reference, as it was a means of protection against evils and harshness of the gods. These fluids also caused revitalization of the heart and prevented exhausting it. Moreover, these Secretions have been released on the earth to remove illnesses and diseases from the body and help the body to be sacred, and become depicted as gods, participating in mobilizing the gods for the sake of the deceased.

Secretions were released from the bodies of gods like Osiris, Isis, and Horus to be sacred. In addition, the body expelled the bad Secretions to get rid of rotten odors and be blessed with perfumes and good odors after that.

In Spell (29) of the Pyramid texts, Secretions are removed to protect the deceased after that from the oppression of the gods ${ }^{4}$ and the eye of Horus would be safe with it, as is mentioned in the spell:

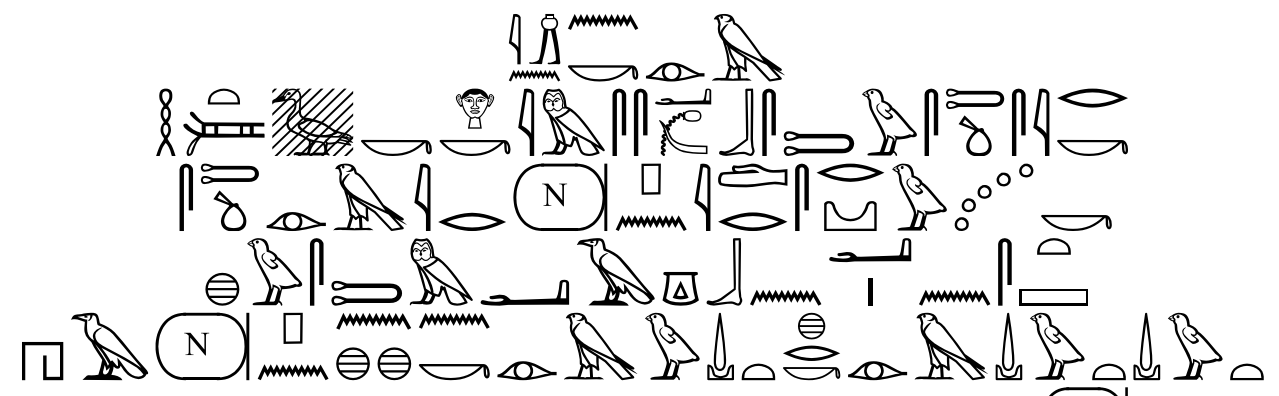

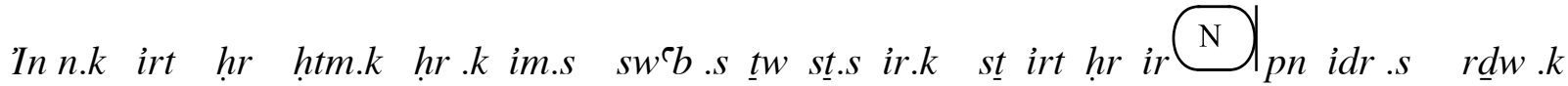

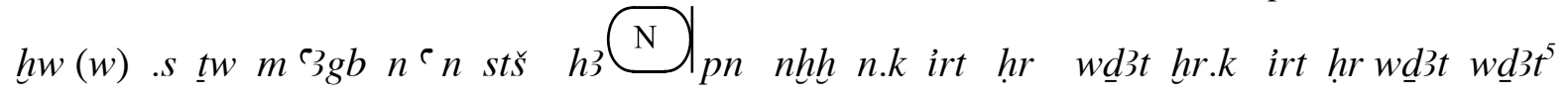


«I bring you the eye of Horus so you might add it (prepare) your face with it so it may purify you ${ }^{6}$, and its perfume is for you and the perfume of Horus's eye ${ }^{7}$ is for this King $\mathrm{N}$ so it might remove your Secretions and protect you from the striking (harshness) of Seth's arm O King $\mathrm{N}$ so »

The healthy eye of Horus was a reason for removing the Secretions and after that the protection from the oppression of the god Seth. It appeared in the events of spell 32 of the Pyramid Texts to indicate that Secretions coming out of the body help the heart and that it would not become sick (or exhausted) because of it, as the spell reveals ${ }^{8}$ :

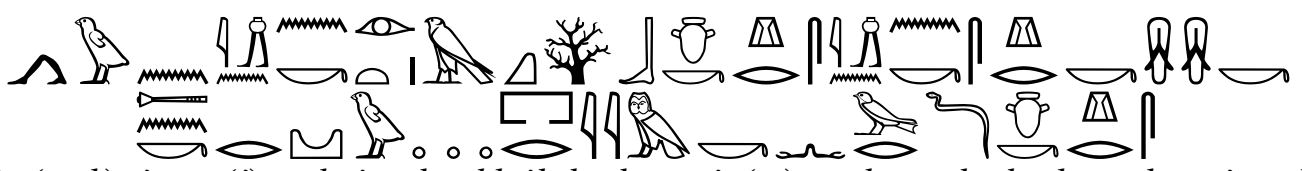

Iw n. (i) (n.k) in.n.(i) n.k irt hr kbib.k hr.s in(w) n.k sy hr.k țbwy.k mi n.krdw pr im.k $n$ wrd $i b . k$ hr.s. ${ }^{9}$

«I came to you and brought you Horus's eye, your heart will be rejuvenated by owning it. I got it underneath your sandals take your own Secretions coming out of you and your heart will not get exhausted of them ${ }^{10}$.

Spell $258^{11}$ of the Pyramid texts states that the illnesses and diseases are all removed when the deceased king releases his Secretions on the earth as follows ${ }^{12}$ :

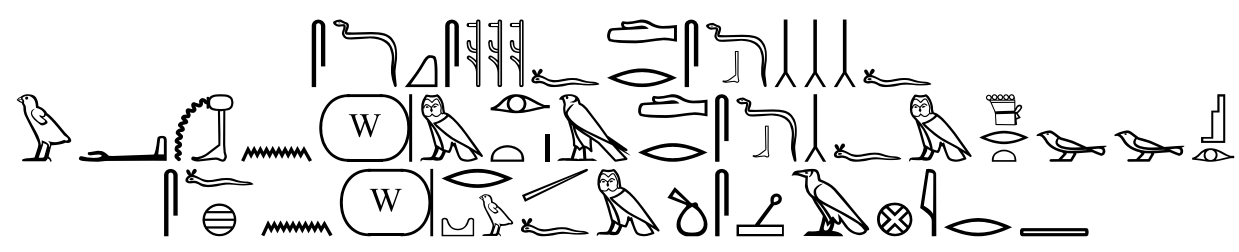

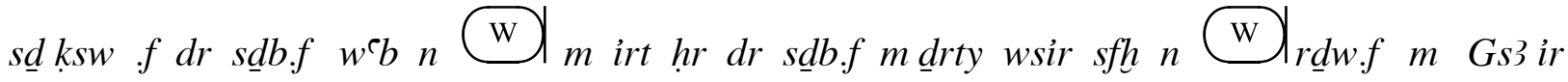
«I broke his bones and the king $\mathrm{w}$ has become pure through Horus's eye and his illnesses have been removed through Osiris's kites, the king $\mathrm{w}$ has released his Secretions on the earth in Qus» ${ }^{13}$. Moreover, the events of spell 508 of the Pyramid texts

\footnotetext{
${ }^{6}$ About purification and its different rite views: BLACKMAN 1924: 47-49; PETRIE 1932: 214; BRUNTON 1937: 33,1; FRANKFORT 1949: 21,53,154; FAIRMAN 1954: 216.

${ }^{7}$ «Horus» 's eye connotes good health, safety, and protection. It also represents the eye of the moon. Maintaining it from Secretions is considered a grant of protection and safety:

PETRIE 1906: 46; BUDGE 1930: 141; MANFRED 1980: 87-93; MANFRED 1980: 87-93.

${ }^{8}$ SETHE 1908: 15; SPRUCH 32: 22b - 23a.

${ }^{9}$ CARRIER 2009: 634, P/F/N e [15-23].

${ }^{10}$ MERCER 1952: 25; FAULKNER 1969: 6; ALLEN 2005: 19.

11 SETHE 1908:147; SPRUCH 258, 308d-308.

${ }^{12}$ CARRIER 2009: 86.

${ }^{13}$ MERCER 1952: 82; FAULKNER 1969: 68; AllEN 2005: 46.
} 
pointed out that the Secretions of the deceased king are those of Horus, after which he is ornamented with perfumes to ascend to Heaven among the gathering gods, after performing purification rites that took place by drinking grape and fig wine, after performing the sacrificial rituals, where the spell pointed out the following ${ }^{14}$ :

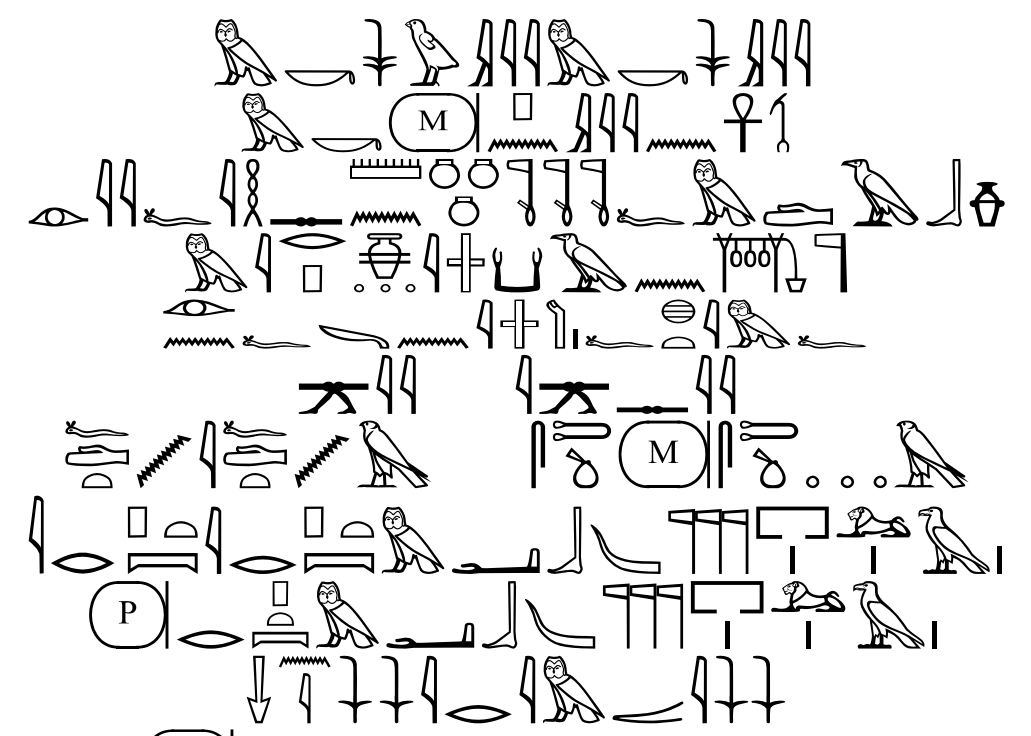

Mk sw ii mksw ii $m k \mathrm{M}$ pn ii $n$ enhw3s iry.f I hsmn.f $m$ d3b m irp imy k3n ntr ir n.f

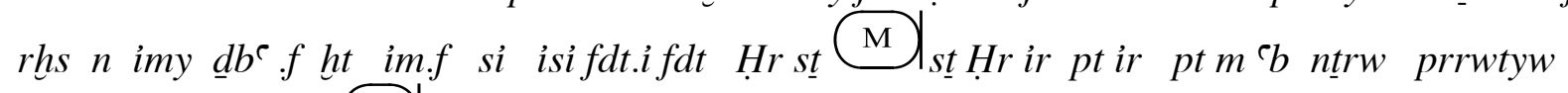
P r pt $m$ eb ntrw prrwtyw sn.i nn ir im $g s . i n n^{15}$

«Behold, you came, behold you came, behold O King $\mathrm{M}$, you came into life and authority (strength). I will prepare the purification from the god's ${ }^{16}$ fig and grape wine and I will prepare the sacrificed under his fingers and the meal (offering) from it. When he goes, he captures attention. My Secretions are those of Horus; my perfume is that of Horus. To Heaven, to Heaven, among the emergent ascending gods, $P$ King ascends to Heaven with the gathering ascending gods, and this is my brother by my side ${ }^{17}$.

The events of spell 533 of the pyramid texts also handled the speech about Secretions of gods' bodies where the blood came out of Re and Sweat and Secretions from Isis's body, the following meaning is revealed ${ }^{18}$.

\footnotetext{
14 SETHE 1908: 121-122; SPRUCH 1112a-1114 c.

${ }^{15}$ CARRIER 2009: 810, P/A/S62-66.

16 The wine was among the most important offerings which were represented to kings and gods and it was related to many gods like Osiris and Sekhmt. It appeared in myths like that of human destruction and was used as an appetizer and a holy presentation for more See:

HASSAN 1828: vol.5, 88; LUCAS 1928: 3; BRUNNER 1954 :81-83; HELCK 1971: 84.

${ }^{17}$ MERCER 1952: 190; FAULKNER 1969: 183; ALLEN 2005: 357, 140.

18 SETHE 1908: 214; Spruch 533, 1263a,c.
} 


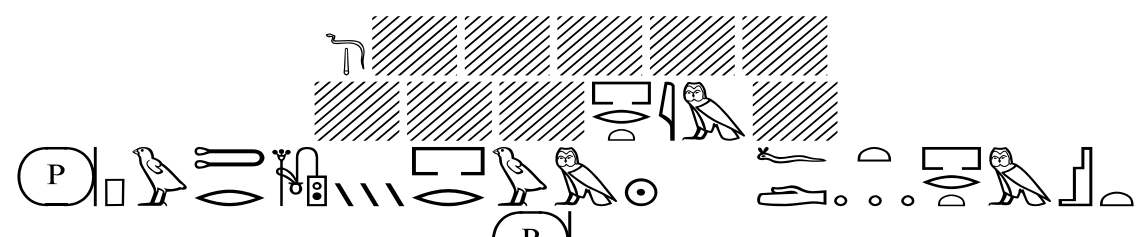

dd $m d w \ldots . . . p r t$ 'I $m,,,$, P $\mathrm{P} w$ tr pr $m R^{e}$ fdt ${ }^{19}$ prt $m 3 s t^{20}$

«Recitation .... That came out of king $P$.It is blood ${ }^{21}$ that came out of Re, and the Secretions that came from Isis» ${ }^{22}$.

And in other spells the deceased king hoped not to have Sweat and Secretions, meaning rotten Secretions, that make him discarded in the Hereafter. And by this meaning, spell 535 pointed out the following ${ }^{23}$ :

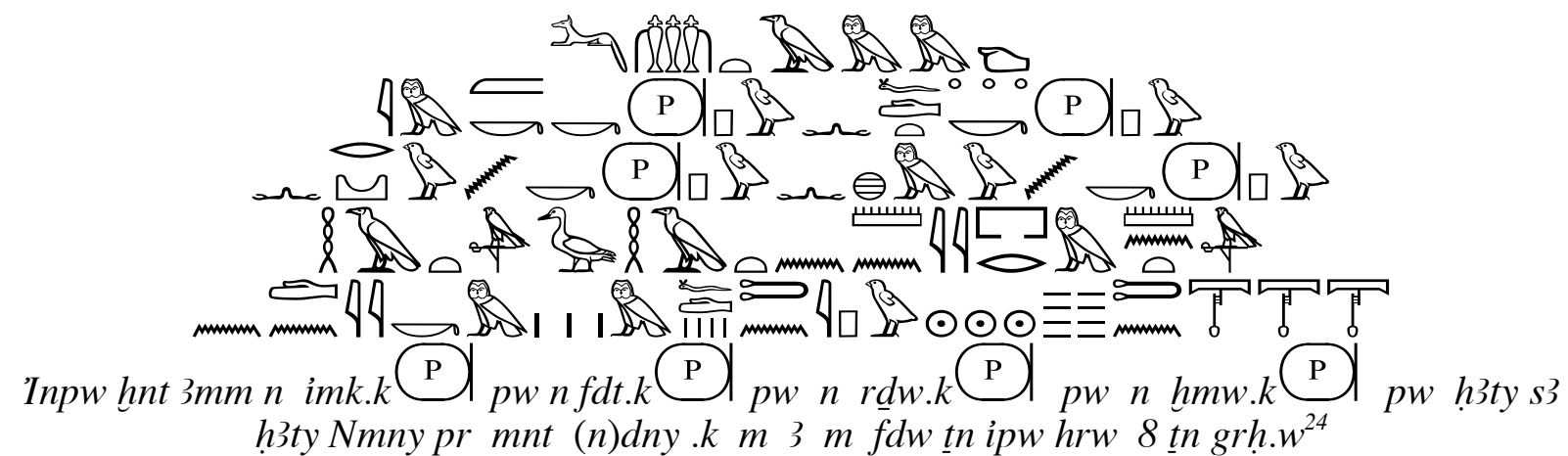

"Anubis comes foremost of grips. You will not be rotten. He is king. You shall not have Sweat. He is King. You will not have Secretions. He is king . You shall not have sand. He is King . The mooring, the mooring, Nmny? He, who came from mnt (place of mooring post), and you have been cut (torn) into three (pieces) in four days and eight nights».

Thus, Sweat and Secretions were the symbolism of sand ${ }^{25}$ among the hateful or discarded things that rot the deceased body, so that he hoped they do not appear to him

\footnotetext{
${ }^{19} \mathrm{About}$ the word fdt and its various meanings as: Sweat and Secretion see:

ERMAN \& GRAPOW (eds.): Wb. vol.1: 9 (6-11);

FAULKNER 1962: 99; LESKO 1982: 166; HANNIG 1995: 308.

${ }^{20}$ CARRIER 2009 I: 928, P/c/ant/ W99- 102.

${ }^{21} \ll$ Blood was considered among the detested things in the hereafter and which he had to get rid of but it was at other times holy as it was related to some gods like «Isis», «Hathor», «Re», «Sekhmet» For more See: FRANDSEN 1979A: 135 -137; FRANDSEN 1979 B: 345; DAUMA 1979: 724.

About butchers and blood shedders, See: SZPAKOWSKA 2009: 802.

${ }_{22}$ MERCER 1952: 208; FAULKNER 1969: 200; ALLEN 2005: 482, 166.

${ }^{23}$ SETHE 1908: 220; Spruch 535, 1282b-1284 b.

${ }^{24}$ CARRIER 2009: 1736, N/c/ant/ E 35- 40.

${ }^{25}$ Sand is spread in the Ancient Egyptian environment due to the geographical location of Egypt in the northeastern corner of Africa. Ancient Egyptians considered sand as one of the basic elements of nature and characteristics of the universe and lifelike heaven, earth and water, but at other times, it was discarded and considered an obstacle and enemy to the deceased. For more see:

BUDGE 1912: 66-67 (14-20), PL. LXXXV; BORCHARDT 1913: PL. 17; EDGERTON \& WILSON 1936: 61; DERCHAIN 1965: PL. 8 (VI 9-10); BEINIICH 1991: 251 (1121).
} 
In the hereafter. He denied his relation to them. In addition, Anubis ${ }^{26}$, god of the Cemetery, played his role in the spell in maintaining the body of the deceased king, so he would not rot and his Secretions would be expelled.

Here, the relation between Secretions and gods of the hereafter appear and the scene of the god Osiris stands out, he from whose body Secretions come out to be purified and he ascends with them to Heaven which opens its doors for him, where spell 536 depicts the following ${ }^{27}$ :

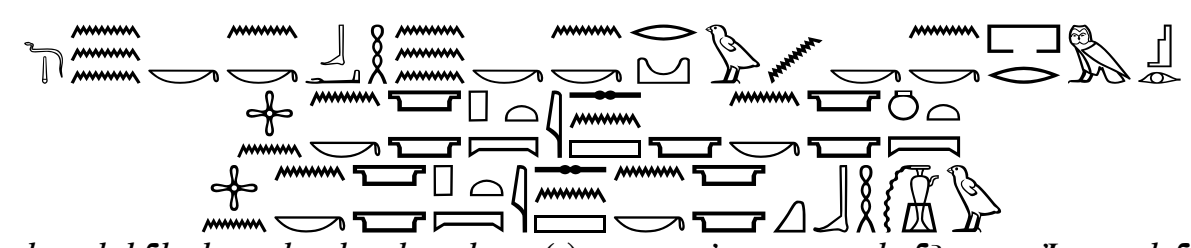

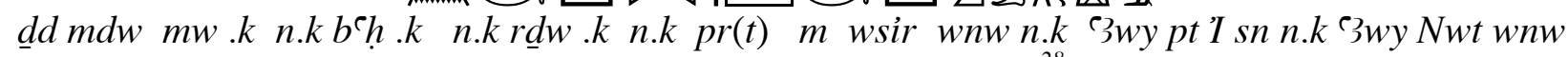
$n . k$ Зw ypt I sn n.k $3 w y \quad k b h w^{28}$

«Recitation: Your water is for you; your flood is for you; your Secretions that came out of Osiris are for you. I opened the two Heaven gates for you. I opened the gates of "Nut"; I opened the two gates of Heaven, I opened the two gates of Heaven for your sake $(k b h w) » .^{29}$.

The same concept is repeated in spell 553 of the pyramid texts, where the Great Bull King crosses the green fields and put aside his rotten Secretions to ascend purified to Heaven where the spell states ${ }^{30}$ :

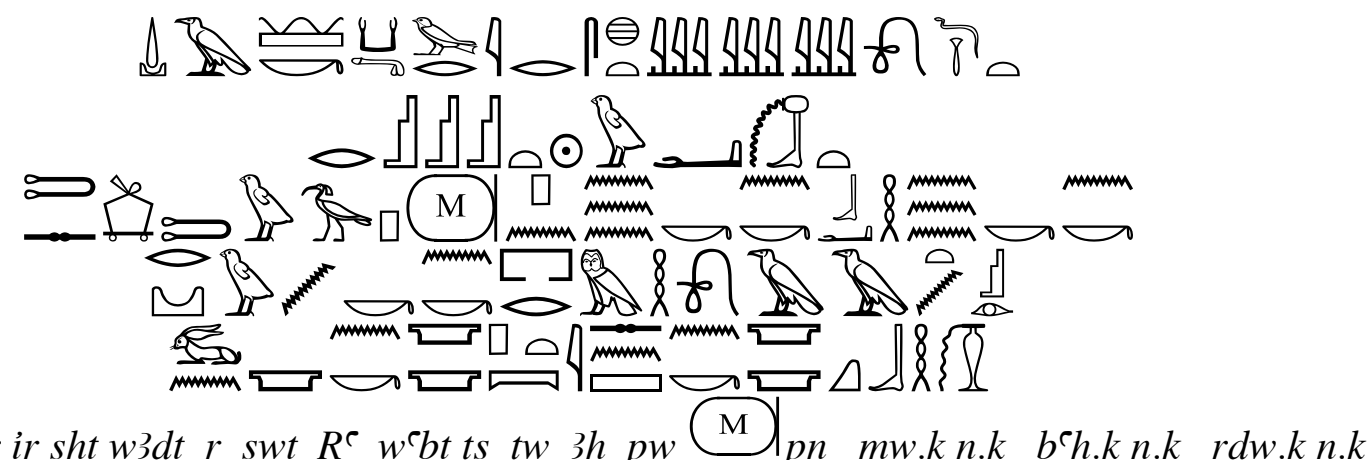

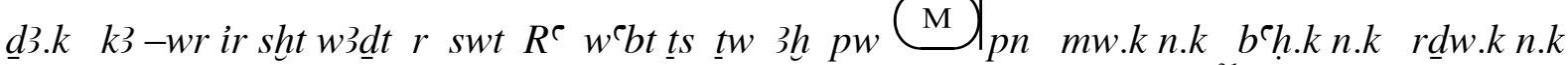
pr $m$ hwst wsir wn n.k $3 w y$ pt isn $n . k$ `wy $k b h w^{31}$

«You may cross $\mathrm{O}$ great bull to the green fields to Re's pure places. Raise yourself $\mathrm{O}$ king's spirit your water is for you and your flood is for you, your Secretions that came out of Osiris's rot are for you, opening for you the two gates of Heaven, opening for you the two gates of Heaven $k b h w »{ }^{32}$.

\footnotetext{
${ }^{26} \mathrm{About}$ Anubis as a god of the cemetery and bodyguard and his different roles, see: DUQUESNE 1996A: 66-97; DUQUESNE 1996 B: 25 - 38. LEITZ 2002: 390; WILKINSON 2003: 187- 190.

27 SETHE 1908: 224; Spruch 536, 1291 a- 1291 c.

${ }^{28}$ CARRIER 2009: 960, P/C/ant /E 58-66.

${ }^{29}$ MERCER 1952: 211 -212; FAULKNER 1969: 205; ALLEN 2005: 484.

Concerning the word $« k b h w »$ meaning heaven, or one of the layers of the horizon. Look up:

ERMAN \& GRAPOW $W b$ (eds.): 30(1-3).

30SETHE 1908: 245; SPRUCH 553, 1359 a - 1361 a.

${ }^{31}$ CARRIER 2009: 1752, N/V/ E 5-7.

32 MERCER 1952: 220; FAULKNER 1969: 213; ALLEN 2005: 526,187.
} 
In spell 659, the deceased king is depicted in the role of the shepherd and his Secretions stop so he receives his white teeth after that in the pot, the meaning of course, revitalization of the body and returning its organs once more, stating the following ${ }^{33}$.

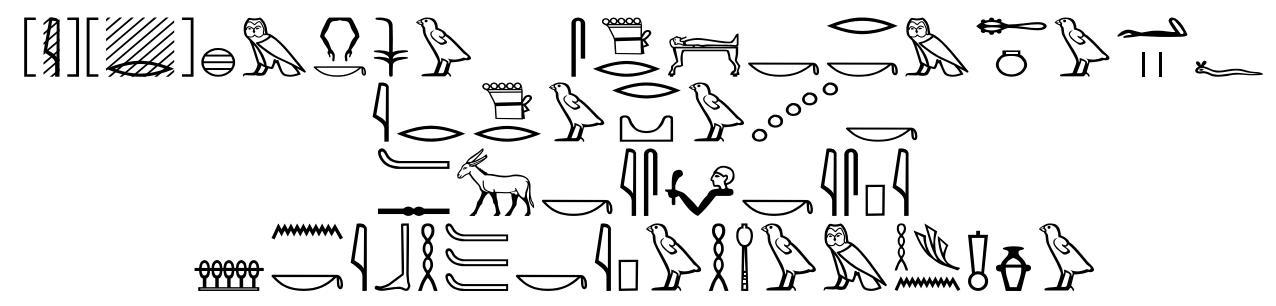

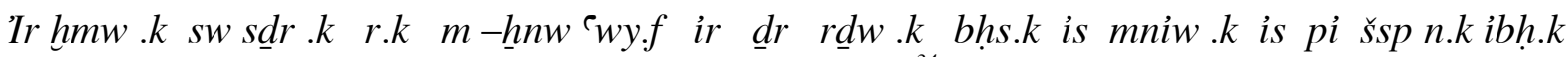
ipw $h \underline{d} \underline{w} m h n w^{34}$

«If you don't know him, you will lie in his laps (in his arms), and I will stop your Secretions, as he is your calf and your shepherd. Receive your white teeth that are in the pot $»^{35}$.

Here, the secretions of the deceased stopped and he received his white teeth in the pot as a step of returning to life, retrieving his organs ${ }^{36}$.

It appeared in spell 676 of the Pyramid Texts, as well, what indicates the stages of the return of the body organs to life and dusting and releasing the bonds of the mummy, so that the deceased king returns to life and ascends to Heaven after that. It described the god's Secretions as those of god Osiris to refer to the holiness of the body and its Secretions. It is mentioned as follows ${ }^{37}$ :

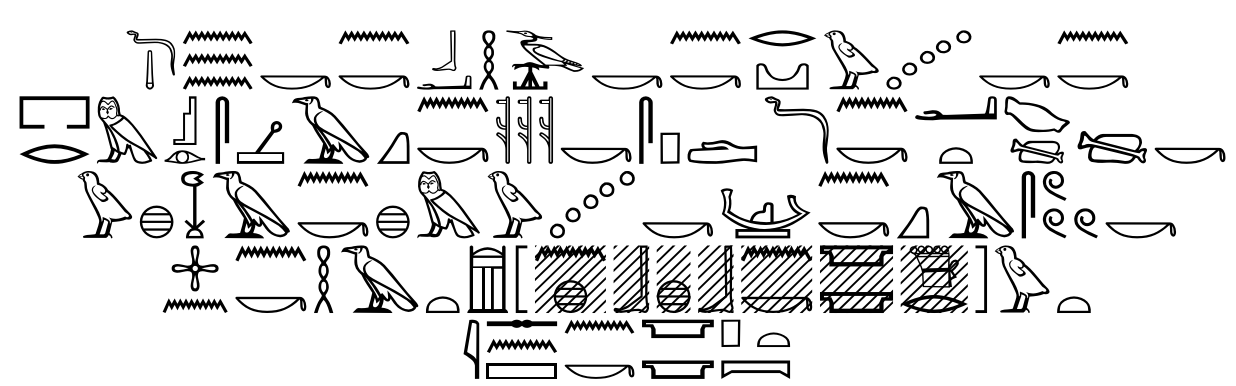

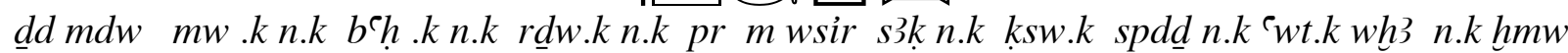
.$k$ wh` n.k k3sw.k wnn n.k h3t nhbhb n.k '3wy drwt.k I sn n.k 3 w y pt.

«Recitation: Your water is for you, your flood; your Secretions are for you, and I have collected your bones for you and ready for your members. Throw off your dust for your sake; your bonds were released for your sake; your tomb has been opened for your sake; the two doors of your coffin were pulled for you, and the two gates of Heaven have been opened for your sake» ${ }^{38}$.

\footnotetext{
${ }^{3}$ SETHE 1908: 454; Spruch 659, 1865a-1866a.

${ }^{34}$ CARRIER 2009: 1350, N/F/En 14-15.

${ }^{35}$ MERCER 1952: 278 -279; FAULKNER 1969: 27; ALLEN 2005: 268, №.302.

36 PEHAL \& PREININGER 2018: 123-126.

37SETHE 1908: 485, Spruch PT 676, 2007a- 2009b.

38FAULKNER 1969: 289; MERCER 1952: 298 -279.
} 
Also, the events of spell 690 of the Pyramid Texts showed that the Secretions coming out of the body rejuvenate the heart and protect it against exhaustion and fatigue, and thus, releasing the bonds of the deceased and his bonds after that, where the spell states the following ${ }^{39}$ :

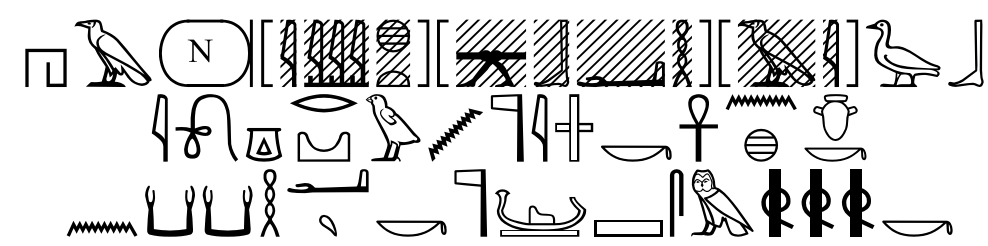

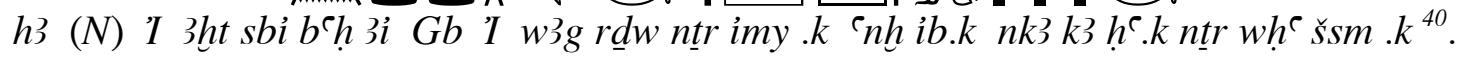

«O king, the flood has come, the inundation is hastening, Geb is being engendered? (born), the god's Secretions in you are provided so that your heart might be live and rejuvenate your body $\mathrm{O}$ god, may your bandages be loosened ${ }^{41}$.

\section{Coffin Texts}

Body Secretions played a great role in Coffin Texts where they were related to the discarded and hurdles of the hereafter, as well as the deceased's hope not to have detested Secretions that may ruin his body and cause his annihilation or destruction. The Secretions coming from the spirits also fell to fill the lakes and make the rivers flow.

In addition, Secretions were related to creation theories for the Ancient Egyptians. The God Shu created the eight gods of chaos from his Body Secretions. The deceased depicted his Secretions Heaven storms and his sweat to incense.

Also, some of the locations in myths were related to Body Secretions, such as «Rostau». Secretions were a reason for the flood, so that it is clear that there is a relationship between Body Secretions and the religious and ideological role of water.

Body Secretions were related to a number of gods to give them special holiness in other instances, like god «Osiris», «Isis», «Geb», «Shu», «Dwa-wr»42.

\footnotetext{
39 SETHE 1908: 515; Spruch 2113-2114b.

${ }^{40}$ CARRIER 2009: 2516, Nt/F/se Inf. 13-17.

MERCER 1952: 307; ALLEN 2005: 294.

${ }^{42}$ God «Dwa-wr»: He first appeared as part of the parade of lower Egyptian gods depicted on the funerary temple of «SAhuree» of the fifth dynasty. Then, his appearance was repeated in scenes with the two gods " $h k$ 3-s «and «hphp», who participated with him in depicting/ embodying the royal signs or symbols on the funerary temple of King Bibi II. Researchers disagreed about explaining the name of the god «rdw3-w» and his job. Most views agreed that he depicts the royal beard and is responsible for the king's ornamentation, as he is the king's barber who washes his face and shaves his beard every morning. see: BORCARDT 1913: PL. 19; JÉQUIER 1938: PL. 60 (3); GARDINER 1944: 29; KEES 1956: 109; LEITZ 2002: 524 .
} 
Moreover, spell 76 of the Coffin Texts handles the myth of creation in Hermopolis ${ }^{43}$ (Ashmunen)where Shu created the eight gods of Chaos (hhw) from the Secretions of his body members.

It mentions the following in this meaning ${ }^{44}$ :

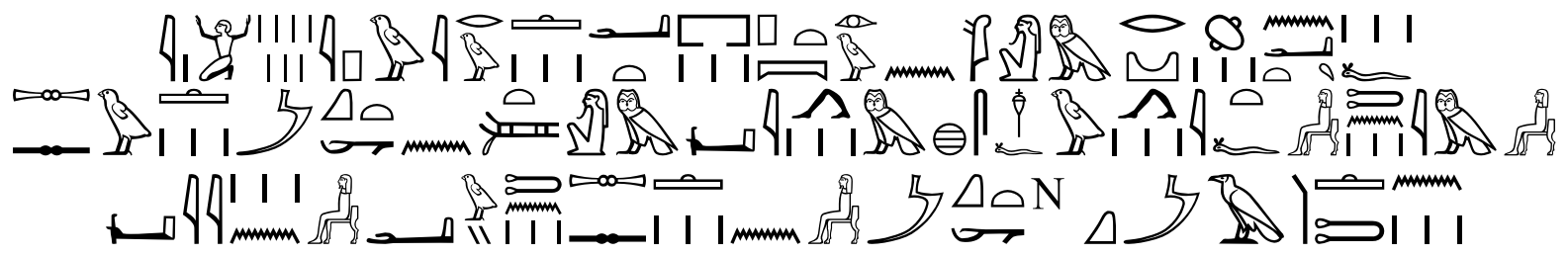

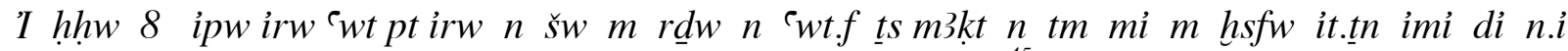
cwy.tn ts n.i m3kt $N \quad \mathrm{~km} 3 . . t n^{45}$.

«O Eight gods of chaos, who are in the charge of the chambers of Heaven, who Shu prepared from Secretions of his members. Knot the ladder for Atum, come and meet your father inside me, give me your arms, tie the ladder of the deceased $\mathrm{N}$ as I prepared you (created you $)^{46} »$.

Here, the deceased resembles his Secretions to the Heaven storm and his sweat to incense. It was among what was stated in spell 80 of the Coffin Texts where it states the following ${ }^{47}$ :

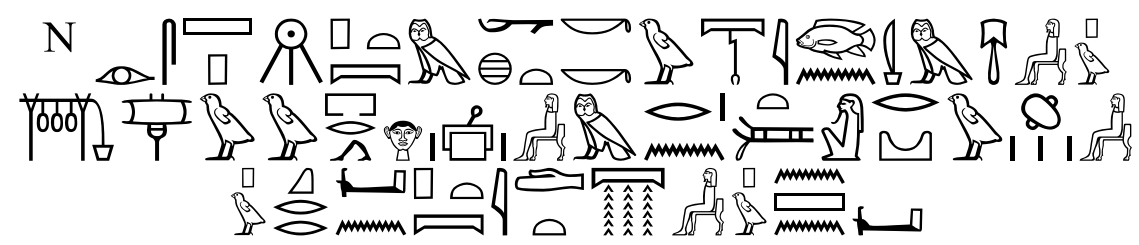

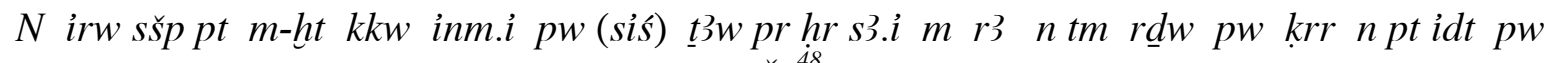
$n \breve{s} n^{48}$

It is the deceased who made Heaven light up after darkness and the pleasant colour of my skin (thanks to) the air that came out behind me from Atum ${ }^{49}$, the storm of Heaven is my Secretions and the incense is my sweat ${ }^{50}$.

\footnotetext{
${ }^{43}$ The theory of creation in $\mathrm{Al}$ «Ashmunein: its idea is summarized in the fact that the origin of the universe is eight powers or elements that lived in the eternal soil and took the forms of frogs and snakes. These elements live in the eternal soil and in water, and they have also created themselves from eternal soil. They are «Nun», «Nunt», «Amun», «Amunt», «Kek», «Kekt», «Heh» and »Heht». These elements were created from Shu's Secretions. See:

SETHE 1929: 48; CLARK 1978: 55; TROY 1986: 16.

${ }^{44}$ BUCK 1935: 1.

${ }^{45}$ CARRIER 2009: 204.

46FAULKNER 1973: 77.

${ }^{47}$ BUCK 1935: 30.

${ }^{48}$ CARRIER 2009: 220.

${ }^{49}$ Atum is the King of gods, an image of the god of the sun. He is the creating god of the universe in the theory Heliopolis.

${ }^{50}$ FAULKNER 1973: 83.
} 
And in reference to the myths of creation, «Hu» ascends to Heaven clearly during the day, while the great spirit is created for Osiris that from which Secretions are derived, along with seeds that help in reproduction and creation. This meaning is clear in spell $96^{51}$.

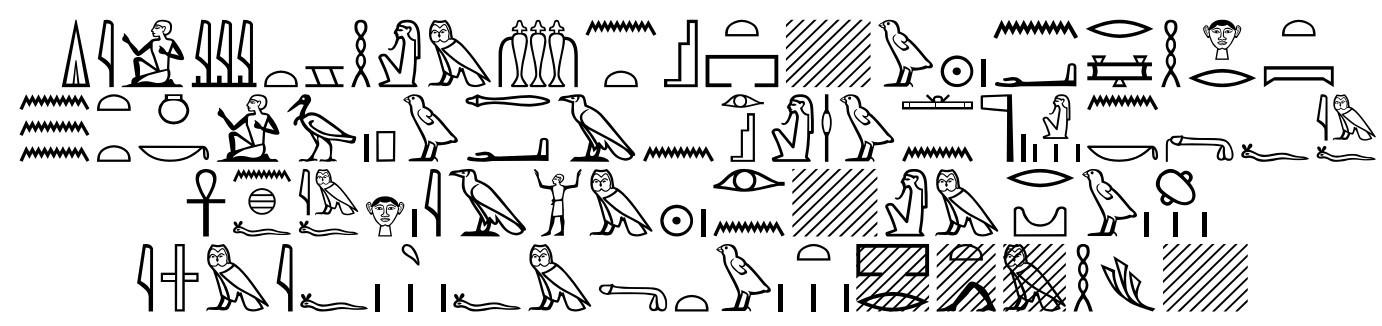

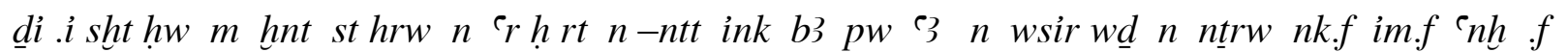
im.f $i 3 \quad m$ hrw ir $n$ (wsir) $m$ rdw imy iwf.f mtwt prt $m$ hnn. $(f)$

«I place $\mathrm{Hu}^{\prime} \mathrm{s}^{52}$ field in front of the seat (throne) which is related to the morning of ascent to Heaven because I am the great spirit of Osiris. I have commanded the gods to copulate with him so he lives in worship in the morning, and he remade Osiris out of the Secretions in his body from the seeds in his phallus» 53 .

Spell 273of the Coffin Texts highlights the role of Body Secretions as an obstacle or impediment feared by the deceased and as one of the foods forbidden to be eaten for being discarded $(b w t)^{54}$ in the hereafter where the following ${ }^{55}$ is mentioned:

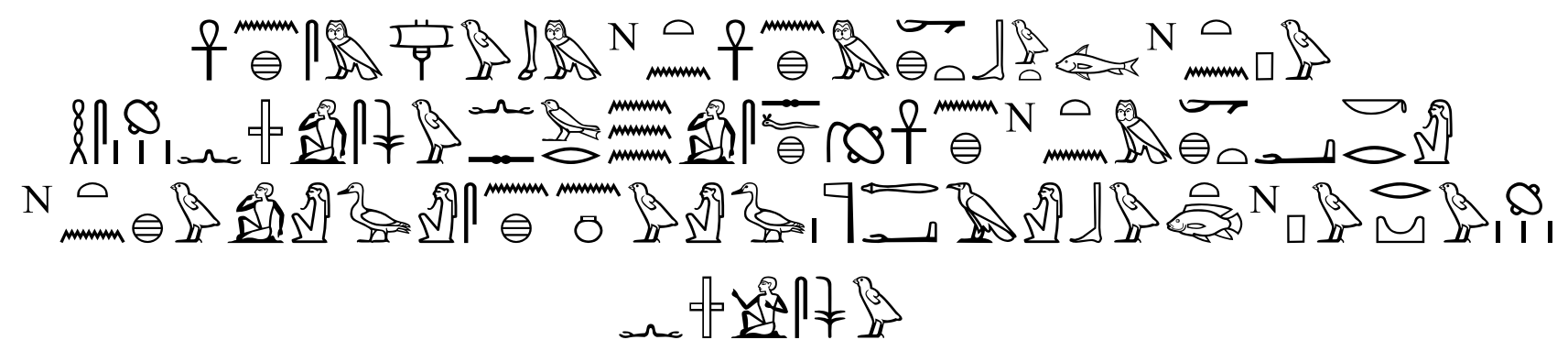

\footnotetext{
${ }^{51}$ BUCK 1935: 76-77.

52 The god $\mathrm{Hu}$ is the power emerging from the creator and an embodiment/ depiction of the creative utterance, for more of his roles, See:

GARDINER 1916: 43; TEVELDE 1970: 175-186; LEITZ 2002: 552-555.

52 FAULKNER 1973: 94.

53 FAULKNER 1973: 94.

${ }_{54}$ «Forbiddance had many faces and cases among which is for the good of a god, person or creature as protection to sacred animals. In addition, it came to avoid hateful thing in the worship rituals like forbidding sexual intercourse with a person or animal or anything or forbidding food, or a certain behavior for more about taboos $(b w t) »$. Among the taboos are: eating feces and Secretions and drinking Urine and Blood. This returns the deceased and gods like $3 k r$ to life. Look up:

MONTET 1950: 85-116; KADISH 1970: 203; FRANDSEN 1985: 151- 158; FRANDSEN 2001: 137; FRANDSEN 2002: 345; JANSSEN 2007: 81-105.

${ }^{55}$ BUCK 1961: 76-78.
} 


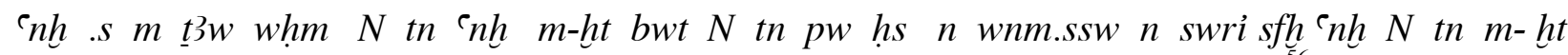

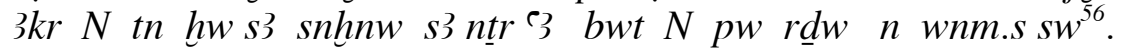

«I live in the air and this deceased (she) repeats it to be alive (in the hereafter) the detestation of this deceased is the filth. She will not eat it, and she will not drink the discharges. She (this deceased) rejuvenates Akr once more (in the hereafter) (she causes Akr to be alive) and this deceased will protect the controller's son the great god's son. The detestation of this deceased is the Secretions and she will not eat the ${ }^{57}$ ».

Spell 236 indicated the mythological location that Secretions come out of and fall out of the body, that is «Rostau» ${ }^{58}$ after ascending to Heaven with Orion and advancing with the entourage of "Re", and by this meaning the spell states the following ${ }^{59}$ :

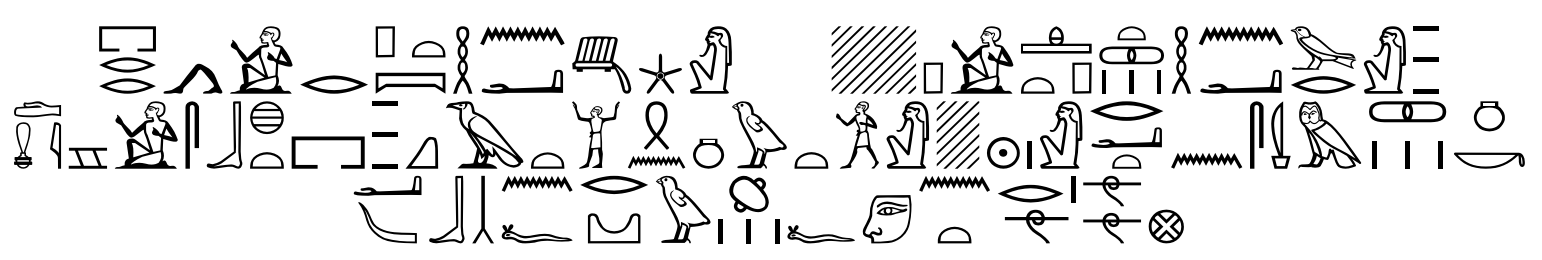

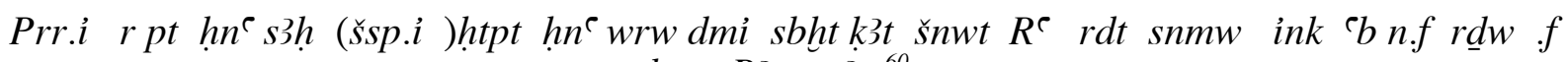
hnt $R 3-s t 3 w^{60}$.

"Ascend to Heaven with orion ${ }^{61}$, and receive the food offerings with the great ones, my adobe is at the high gate and the entourage of Re who prepare the food needs. It is I who will collect for him his Secretions (on the head of) Rosta» ${ }^{62}$.

It appeared in spell (647) of the Coffin Texts what indicates that Isis was created from the Secretions of « Geb» (or his sweat) where the spell states the following: ${ }^{63}$

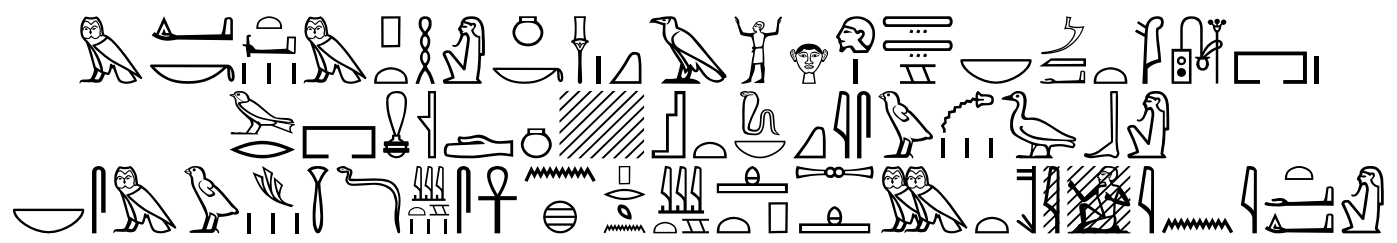

Mkt $m$ pth ink shm k3 hry-tp t3wy nb m3`t šs pr-wr mi kd(ink)... 3st kisw Gb nb

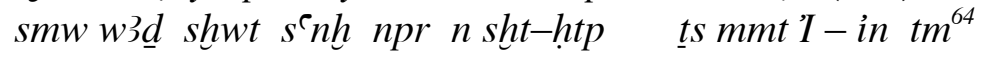

\footnotetext{
56 CARRIER 2009: 430.

57 FAULKNER 1973: 149.

${ }^{58}\langle R-s \underline{t} 3 w »$ many explanations were presented for the derivation of the word. It is probable that the translation is «mouth of under tunnels»- maybe not narrow tunnels- ramp- in reality - but a wide desert extended located between Giza and Sakkara as thought in researchers' views. For more, see:

ZIVIE 1984: 305-309; EDWARDS 1986: 27-36.

${ }^{59}$ BUCK 1961: 304.

${ }^{60}$ CARRIER 2009: 574.

${ }^{61} s 3 h$ is a group of stars in the North Pole including a series of other stars and moving planets. Researchers believed that Ursa Minor group followed the pathway of the Orion «s $3 h$ » in Northern hemisphere. Notice that the nature of the stars forming the «s3h» constellation was debatable among Archeastronomers. Look up
}

WAZIRY 2015: 114.

62FAULKNER 1973: 185.

${ }^{63}$ BUCK 1961: 267. 
«Protection through Ptah he is highly powerful on the headmen of the two earth, Lord of justice, writer of the pr_wr like the shape... it is Isis Secretions? Geb lord of herbage and green fields nourishing for seeds, he will knot the grains? this is what Atum said» 65 .

In addition, Body Secretions were mentioned among offering serving in the events of spell 665 of the Coffin Texts as it stated the following ${ }^{66}$ :

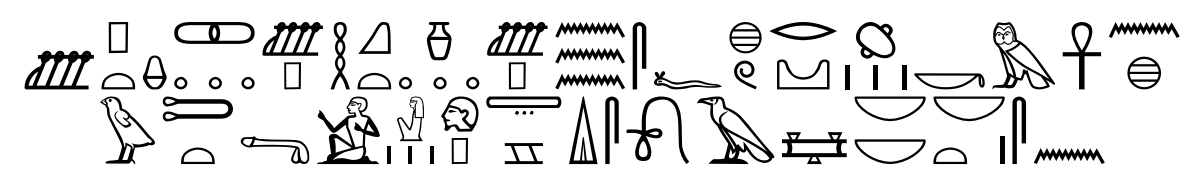

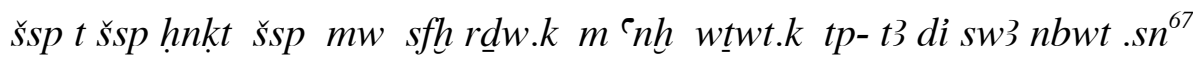

« Receive ${ }^{68}$ bread, beer and water, may your Secretions be released, your children are rejuvenated».

[Your descendants] on the earth and let their baskets pass (their baskets pass) ${ }^{69}$ In spell 810, the deceased resembled his Secretions to those of god Anubis, as it states: 70

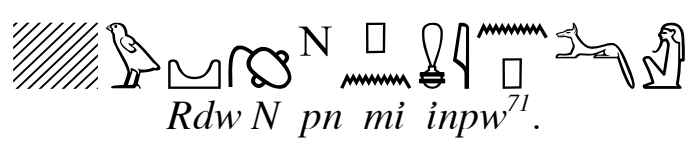

«The Secretions of the deceased are the Secretions of Anubis» ${ }^{72}$.

And for the second time, the role of goddess Isis with the Secretions of the body of the deceased, she is responsible for stopping the Secretions or in other words the body itself from falling to the ground. In this meaning spell 838 of the Coffin Texts states the following ${ }^{73}$ :

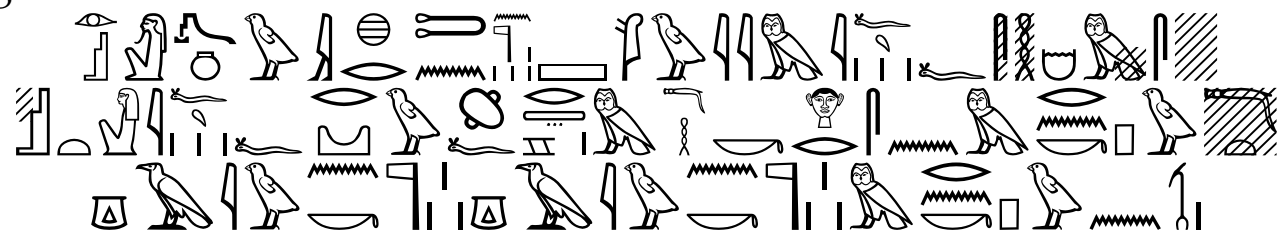

\footnotetext{
${ }^{64}$ CARRIER 2009: 1474.

65 FAULKNER 1973: 221.

66 BUCK 1961: 292.

${ }^{67}$ CARRIER 2009: 764.

68 «Bread was and still is one of the most important foods that Egyptians bear in mind to have on their banquets. Its importance extended to the religious ideological life funerary rites where it was one of the main foods in the hereafter and was used as a meal for gods in the depicted scenes on temples, for example: god Osiris who was connected to bread. He was depicted lying down, with barley ears growing out of his body. For more about bread and scenes on temples and graves, see: WARSHAM 1979: 7-10.

${ }^{69}$ FAULKNER 1973: 237.

70 BUCK 1969: 12.

${ }^{71}$ CARRIER 2009: 1776.

72 FAULKNER 1973: 6.

${ }^{73}$ BUCK 1969: 40.
} 
Wsir nw ï hr.tn ntrw šwy $m$ iw.f snhmm.s 3st iwf.f rdw.f $r$ t3 mh.k hr.sn $m$ rn.k pw mht giiw n.k ntrw giiw n.k ntrw m rn.k pw $n \quad w 3 s^{74}$

«It is Osiris coming to you gods, highness (sublimity) in his body. Isis stopped his body and his Secretions from falling on the ground. You filled what is in them in your name, and the gods praise(admire) you in your name this ${ }^{75}$ is the mace of $\mathrm{WAs}^{76}{ }$.

In spell 1014 of the coffin texts, the deceased worships like Dwa-wr (dw3-wr)and hails with those who (dive) in their Secretions so this event may merge with the rites of worship and glorify the gods as it states ${ }^{77}$ :

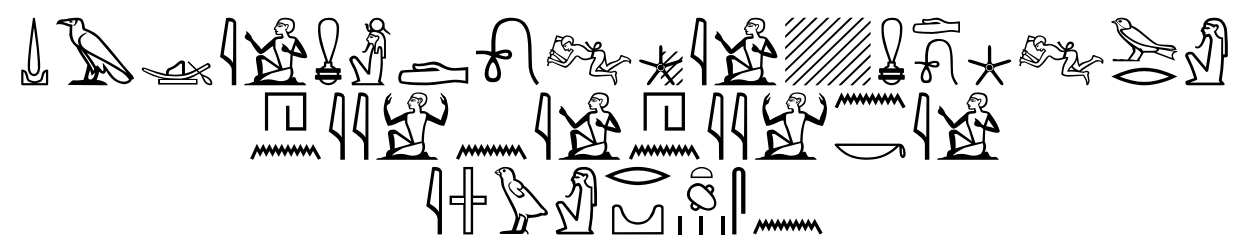

d3.i mi $R^{e} d w 3 . i$ mi dw3-wr hny. n.i hny..n.k I imyw r $\underline{d} w . s n^{78}$.

«I cross Heaven as Re, and I worship like "Dw3-wr" and acclaim and you acclaimed, they who are in their Secretions» ${ }^{79}$.

\section{The Book of the Dead:}

The symbolism of body Secretions in the Book of the Dead came to support the concepts that were presented by Pyramid texts and the Coffin Texts themselves through the relation of body Secretions to some mythological locations like "the fire lake" and "Rostau". In addition, body Secretions related to some gods like the god Osiris who granted them a holy concept, and they were described as pure Secretions.

We start with the events of the chapter (63-B) where the Secretions that come out of the body are only the Secretions of Osiris that he released in the lake of fire ${ }^{80}$ where the deceased had sailed with $\mathrm{Re}$ and where the secretion of Osiris had risen. He also climbed in the light and Khnum ${ }^{81}$ ripped the scourges where the following was stated 82

${ }^{74}$ CARRIER 2009: 1826.

${ }^{75}$ FAULKNER 1973: 26.

${ }_{76}$ PETRIE 1895: 117; WILKINSON 1994: 181; ADREWS 1994: 80.

77 BUCK 1969: 233.

${ }^{78}$ CARRIER 2009: 2154.

${ }^{79}$ FAULKNER 1973: 115.

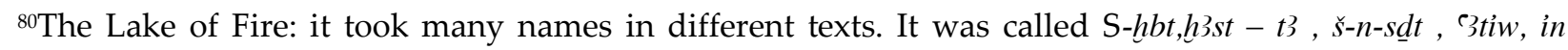
addition to the name suggested here, which is $\breve{-}-3 b s y w$, and iw-nsrsr [Island of Fire], which referred to the Lake of Fire. Its water was described its fiery water as a border in coffin texts [Book of the Two Roads] between the terrestrial and aquatic roads. It is also found in the Book of the Dead, the I, $m y-\underline{d} w^{\top} t$ Book and the Gates Book. In pictures, it took the oval or rounded shape and the rectangular shape in the Imy- Dwat and the Gates Book. For more, see: GRIESHAMMER 1886: 258-259; SETHE 1903: 68 (4-6); SEEBER 1976: 184.

${ }^{81}$ Khnum was related to creation and life. His characteristics were numerous as he appeared in the form of the sheep head and as a maker of pottery. Look up:

LEITZ 2002: 18.

82 BUDGE 1898: 174 [2-4]. 


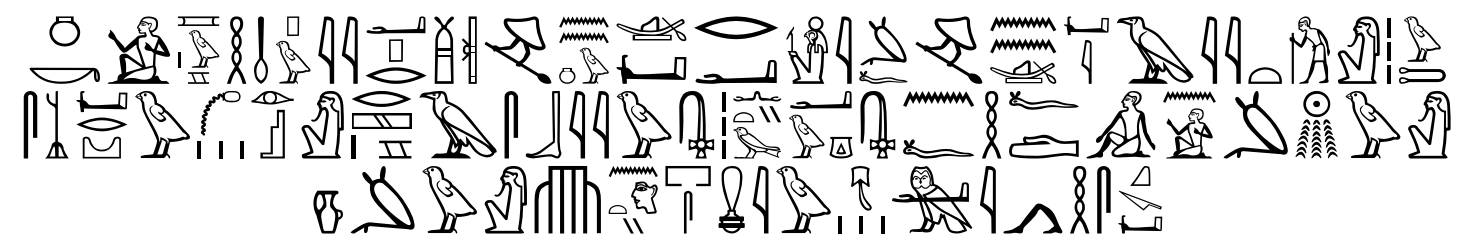

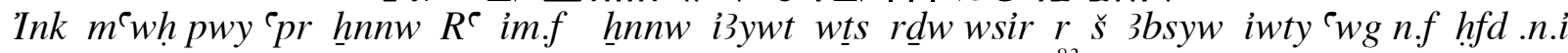
$m$ 3hw hnmw hnty smiw mi hsk $k^{83}$

«I am the prepared oar which Re has sailed with and the ancestors sailed within the lake of fire, the Secretions of Osiris rise in the lake of fire that does not burn. I climbed in the light $\mathrm{O}$ Khnum on the head of scourges (ropes); come to be torn (be cut) into pieces $^{84} »$.

Once more the pure Secretions of the body are released and fall on the land in Rostau so the ceremony of creation and revival is repeated. Ch. 119 states this meaning as follows ${ }^{85}$ :

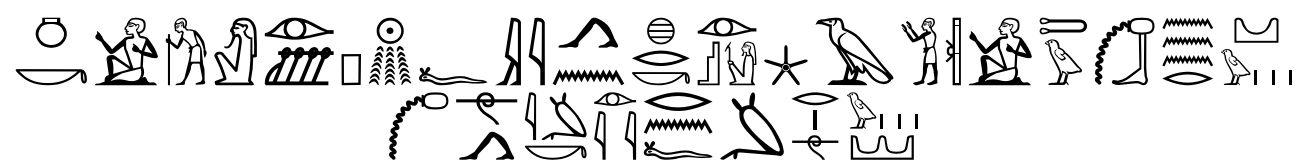

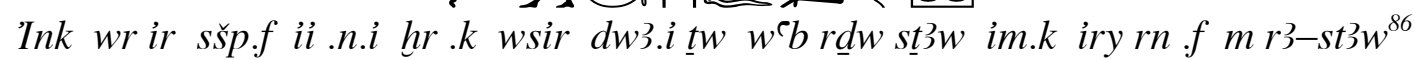

«I am the Great who creates in his light (his own light). I came to you, Osiris, worshipping; your falling Secretions are pure. He has prepared his name in Rostau» ${ }^{87}$.

Finally, the spells of Ch. 149 of the Book of the Dead emphasize that the Secretions are released from the Holy Body of Osiris. The meaning states the events of the Osirian Myth, where the ceremony of the funeral and burial is made for god Osiris. The spells point out the following ${ }^{88}$ :

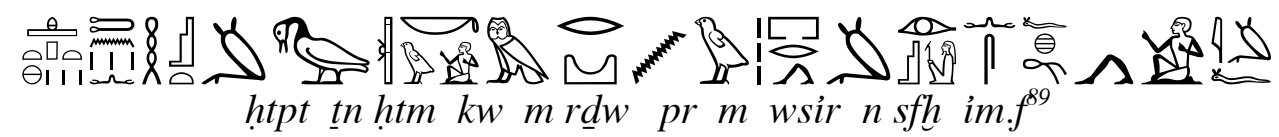

"Your offerings are prepared (set) for you from the Secretions coming out of Osiris, and I will not release them in him» ${ }^{90}$.

\footnotetext{
83 CARRIER 2009: 221.

84 FAULKNER 1985: 69.

${ }^{85}$ BUDGE 1898: 174 [2-3].

${ }^{86}$ CARRIER 2009: 415.

${ }^{87}$ FAULKNER 1985: 113.

${ }^{88}$ BUDGE 1898: 282 [10-11].

${ }^{89}$ CARRIER 2009: 631.

90 FAULKNEFR 1985: 145.
} 


\section{Discussion:}

Body Secretions carry important symbolism and reference, as they were a means of protection against evils and the harshness of gods ${ }^{91}$. They were also a reason for reviving the heart and not exhausting it ${ }^{92}$. They were also released on the land to remove the illnesses and diseases, and they caused the revival of the gods' bodies. Body Secretions played a great role in the hereafter ${ }^{93}$, where the Secretions fell from the spirits to fill the lakes and rivers ${ }^{94}$. Despite that, they were considered, in other instances, an obstacle and enemy for the deceased. The deceased considered them one of the discarded and forbidden things that he avoids and hopes they are not presented as an offering or food in the hereafter ${ }^{95}$. Secretions were also related to mythological locations like «Rostau» ${ }^{96}$ and the «Lake of Fire» ${ }^{97}$.

In addition, Body Secretions were also connected to some gods like: Osiris ${ }^{98}$, Isis ${ }^{99}$, Anubis ${ }^{100},\left\langle\mathrm{Shu}^{101}{ }{ },\left\langle\mathrm{Hu}^{102} »\right.\right.$, and creation gods in general, such as: the eight gods of chaos $\left\langle\mathrm{HH} »{ }^{103}\right.$ which gives them holiness. Here, the researcher will present a table that comprises the key terms indicting Secretions and the development of their shapes through the different eras.

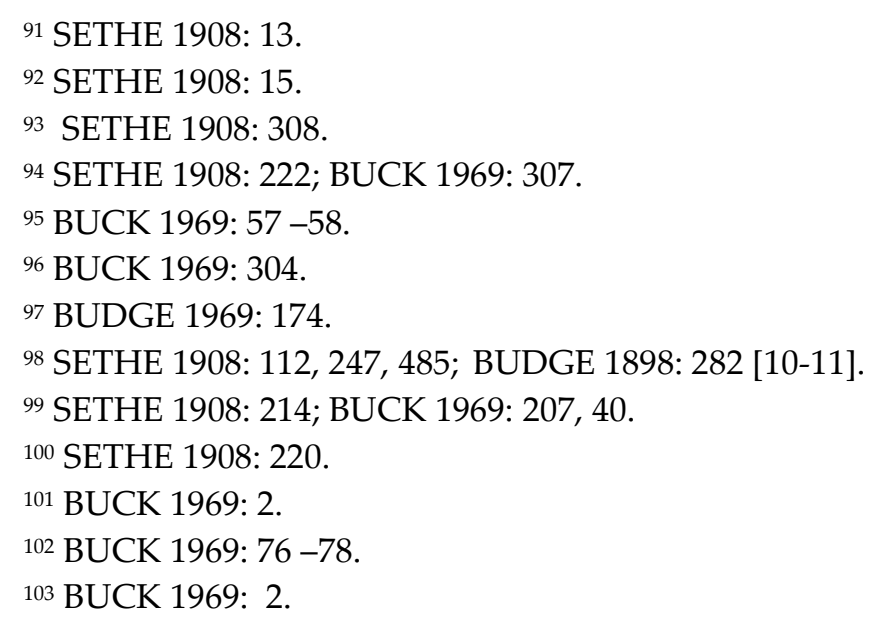




\begin{tabular}{|c|c|c|c|c|}
\hline Word & Transliteration & Meaning & $\begin{array}{c}\text { Determin } \\
\text { ant }\end{array}$ & References \\
\hline$\sim \beta 0_{0} 0^{\circ}$ & $r \underline{d} w$ & Secretions & & PT $29(20, \mathrm{c})$ \\
\hline 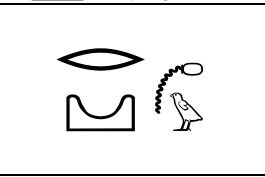 & $r \underline{d} w$ & $\begin{array}{c}\text { Secretions- } \\
\text { Blood-Milk - } \\
\text { Urine } \\
\end{array}$ & & PT $32(23, a)$ \\
\hline$M \beta_{2}$ & $r \underline{d} w$ & Secretions & & PT $32(23, a)$ \\
\hline$\sim$ & $r \underline{d} w$ & Secretions & & $\begin{array}{c}\text { PT } 258(308 f) \\
\text { PT } 553(1360 \mathrm{~b}) \\
\text { PT 690(2114a) }\end{array}$ \\
\hline$\rightarrow \sqrt{n}$ & $r \underline{d} w$ & Secretions & & PT 423(766,c) \\
\hline$\Delta y_{1} / 0$ & $r \underline{d} w$ & Secretions & & PT 423(766,c) \\
\hline$\tilde{\sigma}$ & $F d t$ & $\begin{array}{c}\text { Sweat- Body } \\
\text { Secretions }\end{array}$ & & PT 508(1113,c) \\
\hline$\approx 0$ & $F d t$ & $\begin{array}{l}\text { Sweat- Body } \\
\text { Secretions- } \\
\text { Water of gods }\end{array}$ & ০০০০ & $\begin{array}{l}\text { PT 533(1263,c) } \\
\text { PT 508(1283,a) } \\
\text { PT 637(1801,c) }\end{array}$ \\
\hline$M$ Pros & $\underline{d} w$ & $\begin{array}{c}\text { Body } \\
\text { Secretions }\end{array}$ & rD & CT 74 (CT C vol.2 307) \\
\hline$M B_{1}$ & $\underline{d} w$ & $\begin{array}{c}\text { Body } \\
\text { Secretions }\end{array}$ & 11 & CT 74 (CT vol.1 307) \\
\hline$\Delta \Omega$ & $r \underline{d} w$ & $\begin{array}{c}\text { Body } \\
\text { Secretions }\end{array}$ & ID & CT 74 (CT 307) \\
\hline$\because \beta_{11}$ & $r \underline{d} w$ & $\begin{array}{c}\text { Body } \\
\text { Secretions }\end{array}$ & $\begin{array}{l}111 \\
110\end{array}$ & $\begin{array}{c}\text { CT } 76 \text { (CT vol.1 ) } \\
\text { CT } 80 \text { (CT vol.2 307) } \\
\text { CT } 173 \text { (CT vol.3 58) }\end{array}$ \\
\hline $8 \backsim \beta_{11}$ & $h r \underline{d} w$ & $\begin{array}{c}\text { Body } \\
\text { Secretions }\end{array}$ & $\begin{array}{l}111 \\
111\end{array}$ & CT 318 (CT vol.4 141). \\
\hline$\sum_{m}^{m}$ & $F d t$ & $\begin{array}{l}\text { Sweat- Body } \\
\text { Secretions- } \\
\text { Water of gods }\end{array}$ & $\operatorname{mim}_{\text {mim }}$ & CT 318 ( CT vol.4 141). \\
\hline 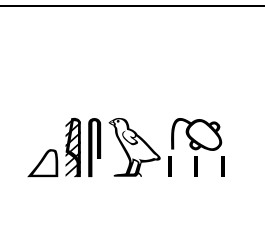 & Kisw & $\begin{array}{l}\text { Sweat- Body } \\
\text { Secretions- } \\
\text { Vomit }\end{array}$ & 10 & CT 647( CT vol.4 267). \\
\hline סمىم & $r \underline{d} w$ & Secretions & & $\begin{array}{l}B D, \text { ch. } 63 \\
B D, \text { ch. } 69\end{array}$ \\
\hline$\sim_{0}^{\circ} \circ^{\circ}$ & $r \underline{d} w$ & Secretions & $0^{\circ}$ & $B D$, ch. 49 \\
\hline
\end{tabular}




\section{CONCLUSION}

Water helped in performing many processes that are vital for body activity of humans, as it helps in swallowing, digestion and distributing nutritive elements on the body, as well as the process of excretion.

Human body elements take the liquid form and water comprises its main component, such as blood, the Lymphatic Fluid, Cerebrospinal Fluid, Seminal Fluid, eye and joint fluids, as well as body Secretions, such as: Sweat, Tears Urine, Milk.

In Pyramid Texts, body Secretions carried important symbolism, where they were a means of protection against evil. In addition, they caused the revival of the deceased's heart and granting him eternal power.

Secretions were released on the land to remove illnesses and diseases from the body, help the body become holy and being depicted as the gods, as well as assembling gods for the deceased. In addition, Secretions were released from the bodies of gods, such as: «Osiris», «Horus »and «Isis» to be by these Holy Secretions. In addition, the body expelled rotten Secretions to be blessed with perfumes and refreshment after that. In addition, Secretions play a great role in Coffin Texts, where it was connected to the discarded and obstacles of the hereafter to fill the lakes and run make rivers flow.

Moreover, Secretions were connected to the Theories of Creation of the Ancient Egyptian, where «Shu» created the eight gods of Chaos from his Body Secretions. The deceased depicted his Secretions as Heaven storms and his sweat as incense.

Some of the mythological locations were connected to Body Secretions, such as « Rostau». Secretions caused floods, which connected Body Secretions to the religious (ideological) role of water. Body Secretions were also connected to a number of gods, so they would give them special holiness in other times, like God «Osiris», «Isis», «Geb», «hu» and «dw3-wr».

All the previous concepts were confirmed in the Book of the Dead, concerning the connection of Body Secretions to some mythological locations, such as «Rostau» and «the Lake of Fire».

Body Secretions were also connected to some gods and had a strong bond, like god Osiris, which granted them a holy concept and were described as being pure.

\section{HOW TO CITE}

cAbdel cAziz, R., «Body Secretions Goddess in Ancient Religious Texts»», Journal of the General Union of Arab Archaeologists, vol. 6/2, 2021. Doi: 10.21608/JGUAA2.2021.49015.1040 


\section{Rania 'Abdel 'Aziz Mahmoud}

\section{BIBLIOGRAPHY}

ABBASY, A.S.: Pediatrics, Faculty of Medicine, Cairo (Dar El Mrref) 1972.

ADREWS, C.: Amulets of Ancient Egypt, London (The British Museum Press) 1994.

ALLEN, J.P.: The Ancient Egyptian Pyramid Text, Society of Biblical Literature, Atlanta (Society of Biblical Literature) 2005.

BEINLICH, H.: «Das Buch von Fayum Zum Religiösen Eigenverstandenis Ägyptischen Landschaft» $\ddot{A} A$ 51, 1991, 251-256 .

BLACKMAN, M.A.: The Story of King Kheops and the Magicians, translated Papyrus Westcar, Berlin Papyrus 3033, England (Davies Reading) 1988.

BLACKMAN, A.M.: «The Rite of Opening the Mouth in Ancient Egypt and Babylonia» JEA 10, 1924, 4759.

BLACKMAN, A.M., «The Significance and Libation in Funerary and Temple Ritual» Z $̈$ S 50, 1912, 69-75.

BORCHARCHT, L.: «Die Dienerstatuenaus den Gräben des AR», ZÄS 35, 1897, 119-130.

BORCARDT, L.: Das Grabdenkmal des KönigsAhu - Rc, Leipzig (Hinrichs'sche Buchhandlun) 1913.

BRUNNER-TRAUT, E.: «Schöpfung» LÄ vol. 5, 1984, 677- 690.

BRUNNER, H.: «Die TheologischeBedeutung der Trunkenheit» ZÄS 79, 1954, 81-86.

BRUNTON, G.: Mostagedda and the Tasian Culture, London (British Museum Expedition to Middle Egypt) 1937.

BUDGE, E.A.W.: The GreenField Papyrus in the British Museum, the Funerary Papyrus of Princes Neistanebtahru, Daughter of Painetchem II and Priestess Neis - Khensunand Priestess of Amun -Re at Thebes, London ( British Museum) 1912.

BUDGE, W: The Book of the Dead, The Chapters of Coming Forth by Day , 3 vols., London (Dryden House) 1898.

BUCK, D.A. : The Egyptian Coffin Texts, 7 vols., OIP 34 , 64, 67, 73, 81, 87, Chicago (The University of Chicago Press) 1935-1961.

BUDGE, E.A.W.: Amulets and Superstitions, London (Oxford University) 1930.

DUQUESNE, T.: «Anubis Master of Secrets (hry-š̌t $)$ and the Egyptian Conception of Mysteries», DE 36, 1996, 25-38.

CARRIER, C.: Textes Des Pyramides de LEgypte Ancienne, Paris (Rue Galande ) 2009.

CARRIER, C.: Textes des Sarcophages du Moyen Empire Égyptien, Paris (Rue Galande) 2004.

CARRIER, C.: Le Livre des Morts, Paris ( Rue Galande) 2009.

CLARK, R.T.H.: Myth and Symbol in Ancient Egypt, London (Thames and Hudson) 1978.

COLLINS, R.O.: The Water of the Nile, an Annoted Bibliiographt, London (Hans Zell) 1991.

DAUMAS, F.: «Besanfitagang», LÄ vol. 1, 1975, 724 -725.

DERCHAIN, P.: Le Papyrus Salt 825 (B.M 10051) Ritual Pour La Conservation de La Vie en Egypte, Le Caire (Institut Français d'Archéologie Orientale) 1965.

DONADONI, A.M.: Egyptain Museum of Turin Egyptain Civilization, Religious Beliefs, Milan (Electa) 1988 .

DUQUESNET.: «Black and Gold God, Colour Symbolism of the god Annubis with Observations on the Phenomenology of Colour in Egyptian and Compartive Religion», in Oxford shire Communication in Egyptology, 5, 1996A, 187-190.

DUQUESNE, T.: « Anubis Master of Secrets (hry-šst3) and the Egyptian Conception of Mysteries», DE 36, 1996 B, 25-38.

EDGERTON, W.F., \& Wilson, J.: «Historical Records of Ramses II, The Text of Medinet Habu, SAOC 12, 1936, 61-65. 
EDWARDS, J.E., «The Shetayet of Rosetau in Lesko», in Egyptological Studies in Honor of R.A. Parker, 1986. 27-36.

ERMAN A. \& GRAPOW H.: Wörterbuch der Aägyptischen Sprache, 7 vols, Berlin (Akademie Verlag) 1971.

FAIRMAN, H.W.: «Worship and Festivals In an Egyptian Temple», Bullein of the John Rylands Library, 1961, 216-218.

FAULKNER, R. O.: The Ancient Egyptian Pyramid Texts, Chicago (University of Chicago ) 1969.

FAULKNER, R. O.: A Concise Dictionary of Middle Egyptian, Oxford (Griffith Institute), 1962.

FAULKNER, R.O.: The Ancient Egyptian Book of the Dead, London (British Museum Publication) 1985.

FAULKNER, R. O.: The Ancient Egyptian Coffin Texts, 3 vols. Warminster (Aris \& Philips), 1973 - 1978.

FRANDSEN, P.J.: «Bwt-Divine Kingship and Grammer», AKVIÄK, 1985. 187-190.

FRANKFORT, H.: Ancient Egyptian Religion, New York (Columbia University) 1949.

FRANDSEN, P.J.: «Taboo», in The Oxford Encyclopedia of Ancient Egypt, 3 vols., Cairo (American University in Cairo Press) 2001, 345- 357.

FRANDSEN, P.J.: «Tabu»LÄ vol. 6, 1986, 137.

GARDINER, A.: « Some Personification» PSBA 38, 1916, 43-54.

GARDINER, A.H.: «Horus the Behdetite» JEA 30, 1944, 23-61.

GRIESHAMMER, R.: «Flammeninsel-iwnsrsr» LÄ vol. 2, 1986, 258-259.

HASSAN, S.: Hymnes Religieux du Moyen Empire , Le Caire (l'Institut Français d'Archéologie Orientale) 1928.

HASSAN, S.: Excavation at Giza, 10 vols., Oxford , Cairo (General Organization for Government Printing Offices) 1929-1960.

HANNIG, R.: Großes Hand Wörterbuch Ägyptisch- Deutsch (2800- 950 V. chr), Mainz (Verlag Philpp von Zabern) 1995.

HELCK, W.: Das Bier im Alten Ägypten, Berlin (Institut für Gärungsgewerbe und Biotechnologie) 1971.

HOLM-RASMUSSEN, T.: «Tabu » LÄ vol. 6 ,1986 C. 135-137.

JANSSEN, J.J.: «The Menstrual Taboo in Ancient Egypt» JNES 66/2, 2007, 81-107, 203-217.

JÉQUIER, G.: le Monument Funéraire de Pepi 2, Vol. 2 -3, Fouillés á Saqqar, Le Caire (Institut Français d'Archéologie Orientale) 1938-1940.

KADISH,G. E.: «The Scatophagous Egyptian» JSSEA 9, 1970, 203-217.

KEES, H.: Götterglaube im Alten Ägypten, Berlin (Akademie-Verlag) 1956.

KLEBS, L.: «Die Reliefs des Alten Reiches (2980- 2475 V. chr)» AHAW 3, 1915, 90-92.

LUCAS , A.: «Egyptian Use of Bear and Wien» AE 1, 1928, 3-4.

- LEITZ, C.: «Lexikon der ÄgyptischenGötter und Götterbezeichnungen» OLA 111 (Leuven - Paris , 2002), 390-392.

- LESKO, L. H.: A Dictionary of Late Egyptian, 5 vols., Berkeley (Scribe Publications) 1982 - 1990.

MANFRED, L.: The Gods and Symbols of Ancient Egypt, New York (Thames and Hudson) 1982.

VMERCER, A.B.: Pyramid The Texts in Translation and Commentary, New York London, Toronto (Longmans, green) 1952.

MONTET, P.: «Le Fruit Défendu» Kemi XI , 1950, 85-116.

PEHAL. M. \& PREININGER P.: «Death and The Right Fluids: Perspectives From Egyptology and Anthropology» JAEI, 2018, 114-136.

PETRIE, F.: Egyptian Decorative Art, New York Arno Press) 1895.

PETRIE, W.M.F.: Religion Life in Ancient Egypt , London (A. Constable \& Co) 1932.

ROTH, A., «The Pšs-kf and The Opening of The Mouth Ceremony, Aritual of Birth and Rebirth», JEA 78, 1992, 113-147. 


\section{Rania 'Abdel cAziz Mahmoud}

PETRIE, W.M.F.: The Religious of Ancient Egypt , London (A. Constable \& Co.) 1912.

SEEBER, CH.; «UntersuchungenzurDarstellung des Totengerichtim AltenÄgypten» MÄS 35, 1976, 184186.

SETHE, K.: Die Altägyptischen Pyramidentexte, 4 Bde, Leipzig (Hinrichs' sche Buchhandlung) 1908-1922.

SETHE, K.: Urkunden der Altägyptischen Allertums, Leipzig (Hinrichs' sche Buchhandlung) 1914.

SETHE, K.: Amun und Die AchtÜrgötter Von Hermoplis, Berlin (Verlag der Akademie der Wissenschaften) 1929.

SETHE, K: Urkunden Alten Reiches 1, Leipzig ( Hinrichs'sche Buchhandlung) 1903.

SZPAKOWSKA, K.: «Demons in Ancient Egypt » Religion Compass 3/5, 2009. 802-807.

TEVELDE, H.: «The God Heka in Egyptian Theology» JEOL VII, №. 21, 1970, 175-186.

TROY, L.; Patterns of Queenship in Ancient Egyptian Myth and History, Uppsala (Universitatis Upsaliensis) 1986.

WARSHNAM, Ch. E.: «Areintepretation of the So-Called Bread Loaves in Egyptian Offering Scenes» JARCE 16, 1979, 7-10.

WAZIRY.A: «Linguistic Symbolic Approach Of Ancient Egyptian Differentiation Between Northern And Southern Constellations», EJARS 5, 2 2015, 97-112.

WILKINSON, R.H.: Symbols and Magic in Egyptian Art, London (Thames and Hudson) 1994.

WILKNSON, R.: The Complete Gods and Goddesses of Ancient Egypt, Cairo (The American University in Cairo) 2003.

ZIVIE, C.M.: « Ro - Setau» LÄ vol. 5, 1984, 305-309. 
معبودات إفرازات الجسد فى النصوص الاينية القديمة

\author{
رانيا عبد العزيز محمود \\ مدرس بكلية الآثار جامعة الفيوم
}

\begin{abstract}
الملخص

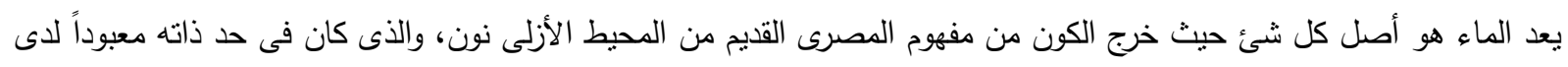

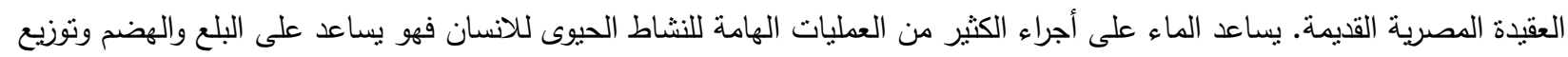
العناصر الغذائية على الجسم وعلى عملية الإخراج. بساعد الماء على موازنة جسم الانسان، ويكون الماء المكون الرئيسى فى الجسد من

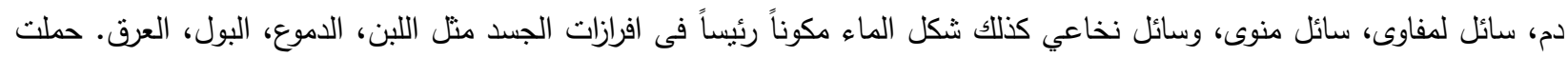

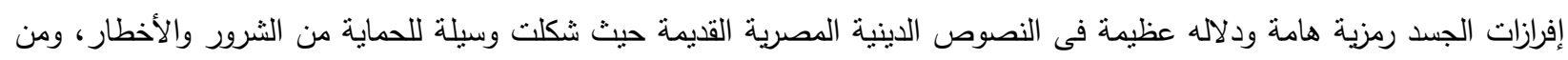

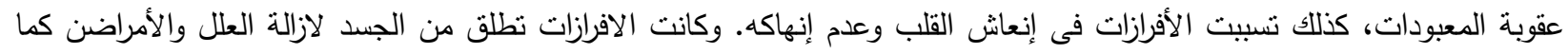

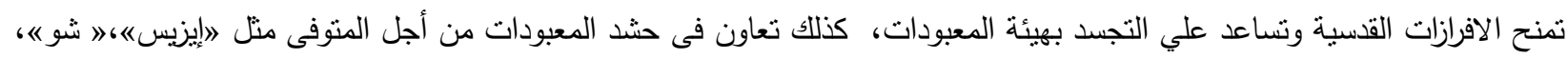

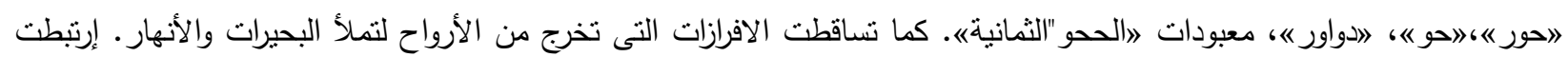

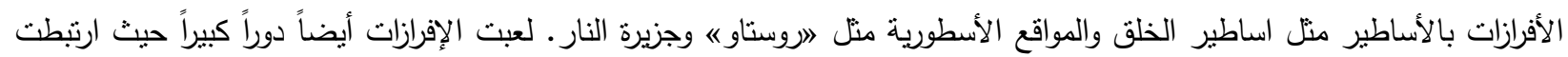

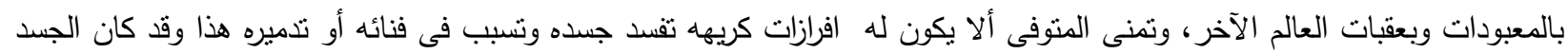
يطرد الافرازات السيئة للتخلص من الروائح الكريهة ولينعم بالعطور والروائح الحسنة بعدها.
\end{abstract} الكلمات الدالة:أفرازات، ماء، عرق، دم، أوزير، إيزيس، حور، اسطورة الخلق، قرابين، جزيرة النار • 